\title{
A review of Finnish Thecophora Rondani, 1845 (Diptera: Conopidae).
}

\author{
Jere Kahanpää
}

\begin{abstract}
Kahanpää, J. 2007: A review of Finnish Thecophora Rondani, 1845 (Diptera: Conopidae). — Entomol. Fennica 18: 168-173.

The Finnish fauna of the conopid genus Thecophora Rondani, 1845 is reviewed on the basis of Finnish museum material from Finland and northwestern Russia. Four species are recorded from Finland, of which T. jakutica Zimina, 1974 is new to Europe. The presence of this recently described species has caused considerable confusion among dipterists before it was correctly identified. Records of $T$. melanopa Rondani, 1857 and T. atra (Fabricius, 1781) from Finland are based on misidentifications. An illustrated key to north European species is provided.
\end{abstract}

J. Kahanpää, Finnish Environment Institute, P.O. Box 140, FI-00251 Helsinki, Finland.E-mail: kahanpaa@iki.fi

Received 31 January 2005, accepted 21 November 2006

\section{Introduction}

The conopid genus Thecophora Rondani, 1845 consists of small, drab grey or blackish flies. Like most parasitoid insects they are rather variable in size, shape and coloration. Identification of specimens is not always easy and often relies on characters present in only one sex. 39 species are known world-wide; eleven of these are found in the Palaearctic region (Chvála \& Smith 1988) and eight from the Nearctic (Camras 1945). Seven species are found in Europe, but it is probable that other, undescribed species are still to be found. The revision of Palaearctic species by Kröber (1925) is now seriously out of date. Chen (1939) has since described two species from China and Lyneborg (1962) one species from Central Europe. Chvála (1965) redescribed all Central European Thecophora species as a part of his larger work on Myopinae and Dalmanniinae. Zimina has described two species from Russia (Zimina 1968, 1974).

Thecophora species are associated with bees (Halictus, Lasioglossum, Apis), but none of the
Finnish species have been reared (Smith 1966, 1989, Zimina 1968).

The Finnish Thecophora material has never been revised. The collected specimens were identified by the original collectors, who seldom had access to reference material of all North European species. This has resulted in great confusion about the number of species present in the country and the relative abundances thereof. This paper aims to settle the identities of Finnish species and provide adequate means for identification of these flies.

\section{Material and methods}

The author has re-identified all Finnish Thecophora material in the collections of the Zoological Museum, Finnish Museum of Natural History $(\mathrm{MZH})$ and the Department of Applied Biology, University of Helsinki (ABH) - a total of 119 specimens. A preliminary version of this paper was sent to other Finnish museums and currently active Finnish dipterists. The bulk of the material 
(from MZH and the author's collection) was preliminary sorted to species level without reference to any keys or descriptions. The resulting groups were then identified using previously published keys and descriptions (Chvála 1965). Clements \& Vincent (2001) provided crucial information on the identity of the Russian species described by L. V. Zimina.

Individual records are listed in the Results section in the following format: Number and sex of specimens, province: municipality, site, (coordinates, if known), date (name of collector). The codes for biogeographical provinces are documented by Heikinheimo \& Raatikainen (1971) and numerous other papers on the Finnish fauna. Coordinates are given in the Finnish national grid coordinate system.

\section{Results}

Four species of Thecophora have been found in Finland. Three of these are well known and widely distributed. The fourth, T. jakutica $\mathrm{Zi}$ mina, has not previously been found in Europe. $T$. melanopa Rondani, 1857 and T. atra (Fabricius, 1781) must be deleted from the Finnish checklist.

The ratio of the length of the basal segment of the proboscis versus the height of the head was found to be a usable character. It is called the proboscis to head $(p / h)$ ratio in this paper. The length of the basal part of the proboscis was measured from the base of palpi to the apex of the basal half. Modified $5^{\text {th }}$ and $6^{\text {th }}$ sternites of females form an organ called the theca (see Fig. 1). The $5^{\text {th }}$ sternite is more or less protruding and has a system of ridges on the posterior face. Similar ridges cover most of the otherwise unmodified $6^{\text {th }}$ sternite.

Females of all Finnish species can be identified by the shape of the theca. The external morphology offers good supporting characters. Thecophora males have fewer external morphological features useful for identification. Reference to the extent and patterns of dusting on the mesonotum and abdomen usually allows reliable identification. Among the Finnish species $T$. fulvipes and T. distincta have characteristic strong dusting patterns. The species with a subshining abdomen (T. pusilla and T. jakutica) are less easy

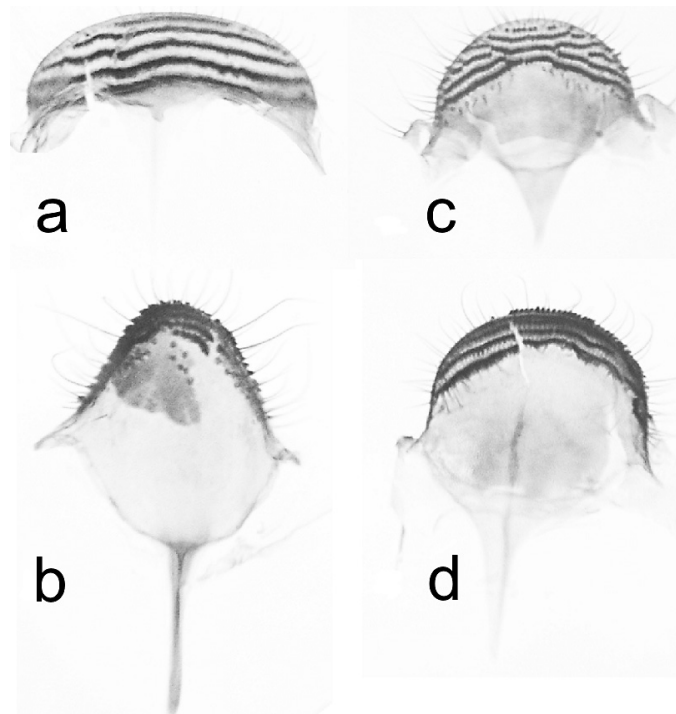

Fig. 1. Theca (modified 5th sternite) of Finnish Thecophora Rondani species. - a. T. distincta (Wiedemann in Meigen). - b. T. fulvipes (R.-D.). - c. T. jakutica Zimina. - d. T. pusilla (Meigen). Scale differs among species.

to identify. The non-Finnish T. atra has a much higher $p / h$ ratio than the T. pusilla/T. jakutica pair.

The high number of misidentifications is explained by the combination of several factors: the variability of characters such as the size, colour and relative size of antennal segments, the presence of $T$. jakutica, a species missing from all identification keys, and the absence of T. atra in Finland. Specimens belonging to T. jakutica were previously identified as T. atra or T. pusilla, causing much confusion since this error made Central European identification keys highly deceptive when applied to Finnish material.

\subsection{Thecophora distincta (Wiedemann in Meigen, 1824)}

Material: Finland 1q, $A b$ : Houtskär (W. Hellén); $1 \delta^{\Uparrow} 1$ 1,$A b$ : Karjalohja (J. Sahlberg); 1, $A b:$ Karjalohja (W. Hellén); 1, $A b$ : Naantali, 27.VIII.1935 (L. Tiensuu); 1 , $A b$ : Naantali (W. Hellén); 1ठ, $N$ : Snappertuna (6657:3309), 16.VIII.1976 (A. Albrecht); 1 ex, $N$ : Espoo (W. Hellén); 1, $N$ : Espoo (R. Frey); 2우, N: Helsinki, Vuosaari (6680:3398), 
18.\&24.VIII.2003 (J. Kahanpää), in coll. JK; 2̧ึ 2 우 $N$ : Vantaa, Korso, 12.VII.1936 (J. Linkola); 1 + $N$ : Porvoo, Weckjärvi, 17.VII.1949 (Nordman); $2 \widehat{\jmath}$ đ 1 , Ta: Hauho (W. Hellén);

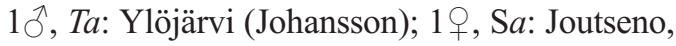
Notko, 15.VII. 1959 (E. Thuneberg); 3 우, Sa: Joutseno, 9.VIII.1949, 25.VIII.1943 \& 25.VIII.1952 (E. Thuneberg); 1ㅇ, Sa: Joutseno (R. Frey); $6{ }^{\lambda}$ 1오 , Sa: Joutseno (W. Hellén); 1§, Sa: Joutseno, 13.VIII. 1956 (E. Thuneberg);

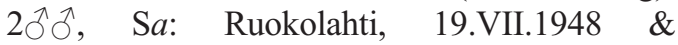
24.VII.1948 (W. Hellén); $1 ð 1$ ○, Sa: Taipalsaari (W. Hellén); 1 , , Kl: Parikkala (W. Hellén). Russia, Leningrad Oblast $3 \hat{\delta} \hat{\sigma} 1$, , Terijoki, 29.VII.1938 (L. Tiensuu); 1今̄, Terijoki, 7.VIII.1937 (L. Tiensuu). Russia, Karelia 1 $\partial^{\hat{\sigma}}$, Sortavala (L. v. Essen); 1q, Sortavala (L. Tiensuu); 1q, Sortavala, 5.VII. 1936 (L. Tiensuu); 1, Säntämä, 20.VII.1941 (L. Tiensuu); $1 \overbrace{}^{\lambda} 1$, , Soutjärvi, 27.VIII.1942 (L. Tiensuu).

Diagnosis: A species characterised by the dense yellow-grey dusting on thorax and abdomen. Frons yellow. $2^{\text {nd }}$ segment of antenna as long as the $3^{\text {rd }}$ segment. Basal segment of proboscis slightly shorter than head is high (average $p / h$ ratio 0.92). Mesonotum covered with yellowgrey dusting, with two narrow dark submedial dorsal stripes and one less well defined stripe on each side. Colour of legs very variable: usually with fore and mid femora partially pale, hind femur dark only in apical third or less. All tibiae basally yellow. The dark areas are covered with pale dusting. $\delta^{7}$ : Abdomen covered with dense, yellow-grey dusting. A narrow dorsal mid-line tapers out in the $4^{\text {th }}$ segment. $q$ : Tergites covered with a dense yellow-grey dusting with shifting patterns. The dorsal surface is also covered with shifting dusting. Theca (Fig. 1a) as wide as base of postabdomen, usually at least partially yellowish.

Notes: Thecophora melanopa was reported from Finland by Thuneberg (1960) on the basis of a single male collected from Joutseno (det. R. Frey). This specimen was found in MZH and it belongs to $T$. distincta. Its hind femora are slightly darker than normal; the yellow basal part does not quite reach the middle. No additional specimens were found. T. melanopa should be deleted from the Finnish check-list.

\subsection{Thecophora fulvipes \\ (Robineau-Desvoidy, 1830)}

Material: Finland 1q, Al: Jomala (W. Hellén); 1 ㅇ, $A l$ : Kökar (W. Hellén); $\widehat{\jmath} \widehat{\jmath}, A b$ : Karjalohja (J. Sahlberg); 1ð, $A b$ : Lohja, 20.VIII.1947 (W.

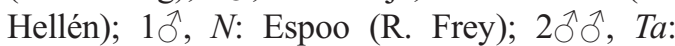
Hartola (68391:34497), 20.VII.2002 (J. Kahan-

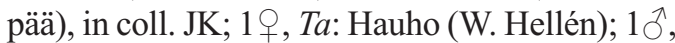
Sa: Joutseno, 16.VIII.1956 (E. Thuneberg); $6 \widehat{\jmath}$ 3 우, Kb: Pyhäselkä, Hammaslahti, 30.VII. 1938-20.VIII.1935 (P. Kontkanen), $1{ }^{\top}$ in ABH; 1ㅇ, $K b$ : Liperi, Koukkelonv. (69502:36257), 18.VIII.2003 (M. Pajari), in private coll. Russia, Leningrad Oblast $1 \hat{\jmath}$ Metsäpirtti, Vaskela, 30.VI.1927 (Pulkkinen). Russia, Karelia 1웅 Sortavala, 23.VIII.1934 (L. Tiensuu); $2 \hat{\jmath}$, Sortavala (L. Tiensuu); $2 \hat{\jmath} \widehat{\jmath}$, Sortavala, 10.VIII. 1935 \& 30.VII.1936 (L. Tiensuu); 1 đ̂, Säntämä, 30.VII.1941 (L. Tiensuu); 1 9 , Säntämä, 24.VIII. 1941 (L. Tiensuu); 1ð̂, Vaaseni, 20.VIII.1942 (L. Tiensuu); $1 \hat{\jmath} 1$ \%, Vaaseni, 9.IX.1942 (L. Tiensuu).

Diagnosis: Frons entirely yellow or brown in upper part. $2^{\text {nd }}$ segment of antenna longer than the $3^{\text {rd }}$. Basal segment of proboscis longer than height of head (average $p / h$ ratio 1.25 ). Mesonotum black, subshining, lateral margins and postpronotal lobes with dense grey pollinosity. Submedial dorsal stripes of pale dusting well developed, wide and non-shifting. Colour of legs very variable: Fore and mid femora usually predominantly pale, but they can be almost entirely dark in specimens from eastern Finland. Hind femora darkened only near the apex. Tibiae usually pale in basal third or more, but some northern specimens have almost entirely black tibiae. Hind tibia not curved (Fig. 2a). $\sigma^{\lambda}$ : Abdomen black with strong, weakly shifting grey to yellow-grey dusting. Mid-line of variable width, often diffuse. + : Abdomen shining black with moderately strong yellow-white bands of dusting. Band on $2^{\text {nd }}$ tergite broad (half width of the segment) but almost broken dorsally, bands on tergites 3-4 diffuse, from some directions appearing narrow, from others covering most of the tergites. Theca (Fig. 1b) of female high and narrow, brownish.

Notes: Females of $T$. fulvipes and T. atra (Fabricius, 1781) have similar theca. The females of T. atra differ from T. fulvipes as follows: mid- 


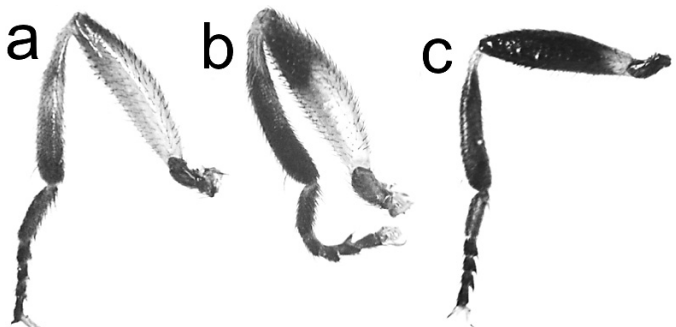

Fig. 2. Hind leg of Finnish Thecophora Rondani species. - a. T. fulvipes (R.-D.). - b. T. jakutica Zimina. c. T. pusilla (Meigen).

dorsal stripes weak. The abdomen has narrow whitish bands along the posterior edges of tergites; sides of tergites 3-5 predominantly subshining. Ventral surface of fore femur darkened (normally pale in T. fulvipes). The coloring and size of $T$. atra is very variable and reliable identification is not always possible.

\subsection{Thecophora jakutica Zimina, 1974}

Material: Finland 1 $\widehat{\jmath}, T a$ : Forssa (R. Tuomikoski); 1 ,,$T b$ : Viitasaari (Wolstedt); $1 \hat{\jmath}, K b$ : Pyhäselkä, Hammaslahti, 15.VIII.1928 (P. Kontkanen), in $\mathrm{ABH} ; 1$, $K b$ : Kontiolahti (Axelson), in ABH; 1 , $K b$ : Nurmes (J. Sahlberg); 1 ,

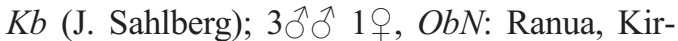
veslampi (7306:3479), 12.VII.2002 (J. Kahanpää), in coll. JK. Russia, Karelia $2 \hat{\jmath} \widehat{\jmath}$, Ruskeala (J. Sahlberg); 1 q, Impilahti (Wolstedt); 10, Hiitola, 31.VII.1924 (E. Thuneberg).

Diagnosis: Frons reddish brown, somewhat paler above the antennal base. The edge of the paler area is usually poorly defined. $2^{\text {nd }}$ segment of antenna slightly longer than the $3^{\text {rd }}$. Basal segment of proboscis short, at most as long as height of head (average $p / h$ ratio 0.84 ). Mesonotum evenly but thinly dusted, with a central paler patch. On the top of mesonotum the grey dusting is slightly brownish in fresh specimens. Submedial dorsal stripes very weakly developed or missing. Fore and mid femora mostly dark, hind femur yellow in basal half to two thirds. All tibiae pale in basal part. Hind tibia curved to a variable degree (Fig. 2b). §̊: Abdomen black with shifting lateral dust bands. The bands are confined to the posterior edges of the tergites in lateral view, but

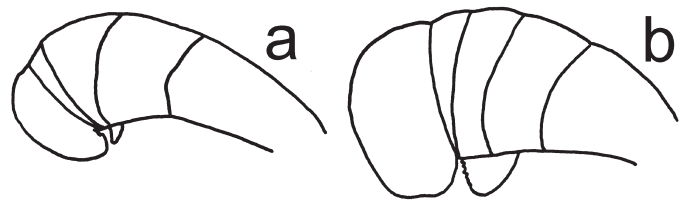

Fig. 3. Female abdomen, showing relative size and position of theca. - a. Thecophora jakutica Zimina. b. T. pusilla (Meigen).

spread to cover the sides of the tergites in posterior or dorsal views. $6^{\text {th }}$ tergite entirely dusted. + : Abdomen black with weak whitish dusting. $2^{\text {nd }}$ tergite with large patches of dusting on sides; in some views these covers much of the posterior half of the tergite. Posterior edges of tergites 3-4 with narrow pale shifting bands. Theca (Fig. 1c) narrow but much shorter than in T. fulvipes, as wide as the apex of the basal part of the postabdomen. It protrudes slightly less than the postabdomen (see Fig. 3a). The ridges on the theca form a complex pattern. No obvious variation is seen in this pattern among the Finnish females (4 exx).

Notes: Previously known only from the type locality (River Nashim - Zhigansk, The Sakha (Yakutia) Rebublic, Russia). The identification was confirmed by Dr. Jens-Hermann Stuke, who compared two Finnish males and one female with a female paratype of $T$. jakutica. The Finnish specimens were collected from the central and eastern part of the country between northern latitudes $61^{\circ}$ and $66^{\circ}$. In Ranua T. jakutica was found on a sandy roadside verge in dry pine heath forest. The ground vegetation was sparse and consisted mostly of heather (Calluna) interspersed with patches of bare sand.

\subsection{Thecophora pusilla (Meigen, 1824)}

Material: Finland $1 \delta^{\lambda} 1 \bigcirc, N$ : Helsinki (6679: 3388), 9.VIII.2002 (J. Kahanpää), in coll. JK; 1̊̄, Sa: Joutseno, Notko, 28.VI.1958 (E. Thuneberg); 1ð̂, Sa: Joutseno, Notko, 1.VII. 1957 (E. Thuneberg); 1 , , Sa: Joutseno (W. Hellén); $1 \overbrace{}^{\top}$, Sa: Joutseno, 2.VII.1945 (L. Tiensuu); 1+, Sa: Joutseno, 1.VII.1945 (L. Tiensuu); 3우, Sa: Joutseno (R. Frey); 2ત̄̄ 1q, Sa: Joutseno, 30.VI.1945 (L. Tiensuu); 1ð̂, Sa: Lappeenranta, 
25.VIII.1976 (E. Valkeila), in ABH; $1 \AA$, Sa: Punkaharju, 30.VI.1950 (L. Tiensuu); 1ठ̀, Sa: Puumala, 13.VIII.1947 (L. Tiensuu). Russia, Karelia 1ð̋ 3우, Vaaseni, 20.VIII.1942 (L. Tiensuu); 2ㅇ, Soutjärvi, 27. \& 31.VIII.1942 (L. Tiensuu); 1ठ, Soutjärvi, 29.VIII.1942 (L. Tiensuu); 1, Äänislinna, 24.VIII.1942 (L. Tiensuu).

Diagnosis: On average the smallest species. Frons blackish in upper half to two thirds, yellow in the lower part. The two colour zones are well defined. $2^{\text {nd }}$ and $3^{\text {rd }}$ segment of antennae of almost equal length. Basal segment of proboscis not longer than height of head (average $p / h$ ratio 0.82 ). Mesonotum black, weakly and evenly dusted. Submedial dorsal stripes absent or very weakly developed. Legs dark: fore and mid femora black, hind femur pale at less only. All tibiae pale only near base. Hind tibia at most slightly curved (Fig. 2c). $\sigma^{\top}$ : Abdomen broadly black on top, sides with shifting areas of dusting covering most of the lateral areas in some views. $6^{\text {th }}$ tergite with a narrow shining band along the posterior edge. Postabdomen shining. $O$ : Abdomen almost shining black, with narrow bands of white dusting on posterior edges of tergites. Theca broad and relatively high (Fig. 3b), larger in proportion than in T. jakutica. Ridges on theca continuous and simple (Fig. 1d).

Notes: The male of Thecophora atra (F.) is very variable and often closely resembles the male of T. pusilla. Single males cannot be reliably identified for the time being. T. atra has not been found in Finland.

\section{Key to North European Thecophora}

Females

1 Mesonotum strongly dusted, with two narrow undusted submedial dorsal stripes. Theca forms a flattened, low and broad arc (Fig. 1a)

T. distincta

- Dusting on mesonotum not as above. Theca higher \& narrower (Fig. 1b-d)

2 Theca very narrow \& high, the exposed part being clearly higher than wide (Fig. 1b) 3

- Theca not as high, exposed part at most as high as wide (Fig. 1c-d)

3 Mesonotum with two well-developed sub- medial dorsal stripes of pale dusting. Fore femur usually ventrally yellow T.fulvipes

- Mesonotum without well-developed submedian dorsal stripes. Fore femur usually ventrally darkened T. atra

4 Theca smaller, in resting position protuding slightly less than the postabdomen (Fig. 3a), with a complex pattern of ridges (Fig. 1c)

T.jakutica

- Theca larger (Fig. 3b), in resting position protuding as much as the postabdomen, with simple continuous ridges (Fig. 1d) T.pusilla

Males

1 Mesonotum strongly dusted, with two narrow undusted submedial dorsal stripes $T$. distincta

- Mesonotum not as above. Submedial dorsal stripes, if present, pale

2

2 Abdomen with strong yellow-grey dusting, shifting pattern weak T.fulvipes

- Abdomen mostly dark, shining or subshining, dusting strongly shifting, most prominent along posterior edges of tergites. These following males can not always be reliably identified and comparison with the diagnosis given above is essential

3

3 Frons reddish brown, somewhat paler above the antennal base. 6th tergite entirely dusted

T.jakutica

- Frons blackish in upper half to two thirds, yellow in the lower part. 6th tergite normally with a shining band along the posterior margin

T. pusilla \& T. atra (see notes under T. pusilla)

Acknowledgements. I'd like to thank Dr. Jens-Hermann Stuke for his critical comments on an earlier version of the manuscript. He did also check the identification of T. jakutica against type material. This study was made possible by financial support from the Finnish Expert Group on Diptera.

\section{References}

Camras, S. 1945: A Study of the Genus Occemyia in North America. - Annls. Entomol. Soc. Am. 38: 215-222.

Chen, S. H. 1939: Étude sur les Diptères Conopids de la Chine. - Notes. Entomol. Chin. 6: 161-231.

Chvála, M. 1965: The Czechoslovak species of the subfamilies Myopinae and Dalmaniinae. - Acta Univ. Carol. Biol. 1965: 93-149. 
Chvála, M. \& Smith, K. G. V. 1988: Family Conopidae. In: Soós, Á. \& Papp, L. (Eds.), Catalogue of Palaearctic Diptera: 245-272. Akademiai Kiado, Budapest \& Elsevier, Amsterdam.

Clements, D. K. \& Vincent, H. 2001: The Conopid taxa described by L. V. Zimina from the former Soviet Union. — Entomol. Mon. Mag. 137: 33-48.

Heikinheimo, O. \& Raatikainen, M. 1971: The recording of localities of biological finds in Finland. - Ann. Entomol. Fenn. 37: 9-12.

Kröber, O. 1925: 35. Conopidae. — In: Lindner, E. (ed.), Die Fliegen der palaearktischen Region IV: 1-48. E. Schweizerbart'sche Verlagsbuchhandlund.

Lyneborg, L. 1962: A new species of Thecophora Rond. (Diptera, Conopidae) with notes on T. distincta Wied. in Meig. 1924. — Entomol. Meddelelser 31: 311-314. Smith, K. G. V. 1966: The larva of Thecophora occidensis, with comments upon the biology of Conopidae (Diptera). — J. Zool. 149: 263-276.

Smith, K. G. V. 1989: An introduction to the immature stages of British flies. - Handbooks for the Identification of British Insects IX, part 14. Royal Entomological Society of London. $280 \mathrm{pp}$.

Thuneberg, E. 1960: Kokousselostuksia - Sitzungsberichte. - Ann. Entomol. Fenn. 26: 293.

Zimina, L. V. 1968: New data concerning the parasitic relationships of conopids (Diptera.

Conopidae). - Zool. Zh. 47: 780-781.

Zimina, L. V. 1974: New data on taxonomy of Conopidae (Diptera). — Zool. Zh. 53: 477-481. 